\title{
The Policy of Indonesian People's Wave Party (Gelora) in Response to the Phenomenon of a Political Dynasty in Indonesia
}

\author{
Muhammad Ali Hanafi ${ }^{1, *}$, Idrus Affandi ${ }^{2}$ \\ 1,2 Universitas Pendidikan Indonesia, Bandung, Indonesia \\ *Corresponding author.Email: muhammad.ali@upi.edu
}

\begin{abstract}
This study aims to find out the policy of Gelora Party in response to the phenomenon of a political dynasty in Indonesia. A political dynasty in Indonesian cannot necessarily be prohibited because it is the right of each individual or group. However, a political dynasty impacts negatively on society such as democratic stagnation, uproar, and obstruction of the regeneration process in each political party. To overcome this, a solution and a new perspective are needed. The policy of Gelora Party is very interesting to be investigated. Because Gelora Party is a new party full of idealism, so it has many new policies in various fields. The policy of Gelora Party is to create new political elites from ordinary people by educating them in order that they are politically literate and aware. Moreover, they have to be financially independent so that their self-esteem cannot be bought. Gelora Party educates political elite candidates from an early age. This is grassroots politics, and it is believed that it can create a strong political network. The typical Gelora Party policy is to create political elites from ordinary people considering that so far many political parties have recruited cadres from educated groups. Therefore, Gelora Party creates a very detailed coaching curriculum to educate their cadres who are ordinary people.
\end{abstract}

Keywords: Gelora Party, Policy, Political Dynasty, Political Party.

\section{INTRODUCTION}

A policy is a matter that greatly affects people's lives; all the more so because the policy is implemented by the government or a group of people who has political control of a country or an area. Good policies will produce good governance. According to Tjokroamidjojo in Bestari [1], the main principles of good governance are accountability, transparency, openness, law, and equality. The government must apply all these principles, especially the principle of equal treatment for everyone.

Discussions about the issue of power have always been a memorable discussion among the people of Indonesia because power is a matter that is obligatory in a country. Indonesia itself has long agreed to a government system led by a president which is commonly referred to a presidential system. Power that has been part of Indonesia for a long time must have a healthy climate. This means that both the internal and external condition of power must be good. This greatly affects the way a country develops.

However, there is a phenomenon known as a kinship politics or a political dynasty in Indonesia. This phenomenon is considered as something that has the potential to hamper open and participatory politics. Problems relating to the power of political parties and also political dynasties that took place in the UK have obtained findings from research that strengthen problems relating to the power of political parties and also this political dynasty. The study shows that the strength of political parties and also political dynasties prevents good political competition. It means that political dynasties have the potential to result in unhealthy political competition, but in terms of human rights political dynasties cannot be prohibited. According to Idrus Affandi [2], letting politics that a relative is nominated as a public official will have a bad impact on the political climate. This is due to the fact that there will be a problem in terms of democracy such as obstruction of the regeneration process and increase of the chances of nepotism, corruption, and collusion.

According to the official website of the Indonesia Election Oversight Body, a political dynasty is when a family that some members become state officials of a country. That there are so many politicians that are in the same family in Indonesia causes problems associated with political dynasties such as in local elections. According to the data presented by the General Election Commission, the 2015 local election was participated by 765 pairs of regional head candidates in 261 regions. Of the 765 pairs of regional head candidates, there were 644 pairs from political parties, 121 pairs from non-political party. Moreover, 155 pairs were incumbent pairs. One of the ways carried out by the incumbents to maintain his/her power is to nominate their relatives to be regional head candidates and build political dynasties. This way is carried out when the incumbents are unable to be the regional head candidates for the next period because they have served for 2 terms. 
Actually, there was an effort to prevent the establishment of political dynasties that was the prohibition of nominating relatives for the incumbents to be reginal head candidates. The prohibition was written in Article 7 letter $r$ of Law Number 8 of 2015 concerning local elections. However, the prohibition was then abolished by the Constitutional Court on July 8, 2015 with the verdict of 33 / PUU-XIII / 2015 which stated that Article 7 letter $\mathrm{r}$ of Law Number 8 of 2015 concerning local elections was against Article 28J Paragraph (2) of the 1945 Constitution. This makes the public worries about the thriving practice of political dynasties because it threats the political condition and is unethical.

The main problem caused by political dynasties is control over natural resources by certain people and also the emasculation of democratic rights; all the more so because the political dynasties are in the legislative and executive institutions. It also increases the chances of corruption. Below is the way how a political dynasty is established.

1. Several members of a family are involved in politics particularly electoral politics. They hold state office such as in the People's Representative Council of the Republic of Indonesia and the Regional People's Representative Council or hold state office as regional heads. With the position, they can have a control over natural resources. This is a proof that the members of a political dynasty can freely control bureaucracy in regions.

2. To establish a political dynasty, it requires a lot of money to maintain a working relationship with political parties, youth organizations, religious organizations, etc.

Therefore, it is very clear that the major political parties in Indonesia are involved in the establishment of political dynasties. This is not done not on purpose or accidentally, but this is done systematically.

One of the political parties that is relatively new in Indonesia is the Indonesian People's Wave Party or commonly abbreviated as the Gelora Party. This party was founded on October 28, 2019 and has vision and mission that is different from other political parties. This is because the Gelora Party has the courage to declare itself in the midst of the increasingly political party competition in Indonesia. As a new political party, it is certainly interesting to review its policies, especially in terms of dealing with the phenomenon of political dynasties.

\section{THEORETICAL REVIEW}

\subsection{Policy}

According to Bestari [3], policy is what the government does and what the government does not do. Moreover, Thomas R. Dye [4] states that policy is a decision that the government has the authority to make authorative decisions such as the decision to let something happen for the sake of resolving a public problem.

Irfan Islamy in Suwitri [5] summarizes the definition of policy. Below is the summary.

1. Harold D. Laswell and Abraham Kaplan define policy as a program of achieving goals, values, and directed practices.

2. Carl J. Friedrick defines policy as a series of actions proposed by a person, group or government in a certain environment by showing the obstacles and opportunities for implementing the policy proposal in order to achieve certain goals.

3. James E. Anderson defines policy as a series of actions that have a specific goal and is followed and carried out by an actor or a group of actors in order to solve a particular problem.

4. Amara Raksasataya defines policy as a tactic and strategy that is directed to achieve a goal. Therefore, a policy contains 3 elements that are:

a. identification of the goal to be achieved;

b. tactics or strategies of various steps to achieve the desired goal;

c. The availablity of multiple inputs to enable the actual implementation of the tactics or strategies.

A policy that is carried out with full preparation and consideration will certainly have a good impact. Therefore, it is necessary to form a good policy with full preparation and consideration. According to Bestari [6], there are 5 steps to make a policy.

1. Problem Formulation: Providing information about the condition that causes problems.

2. Forecasting: Providing information about the future consequences of the alternative policies and if not making policies.

3. Policy Recommendation: Providing information on the net benefits of each alternative, and recommend alternative policies that provide the highest net benefits.

4. Policy Monitoring: Providing information about the current and past consequences of implementing alternative policies including the obstacles.

5. Policy Evaluation: Providing information about the performance or outcome of a policy.

\subsection{Political Dynasties}

Political dynasties are a phenomenon that often occurs, especially in democratic countries. Mosca has concerns about this problem and states that even each political were open to all, a relative of a state official will be given more political advantages (Synder et al. 2009: 115) [13]. In an ideal democratic life, all people have the same opportunity to live political life. This means that the opportunity is very open for all people to compete for political positions from the regional or national level.

An example of political dynasties is a political dynasty in Bangladesh. According to Amundsen [14] in Bangladesh political dynasties were a common thing. 
There are two major political families that are the Awami League and the Bangladesh National Party. Each of them has served the country for 40 and 35 years respectively. Another example is the Hariri political dynasty. According to Vloeberghs [15] that after the murder of Rafik Hariri, the former of prime minister of Lebanon, on February 14, 2005, the Hariri family was under pressure to approve a new leader. Relatives of Rafiq Hariri resolved the problem in about two months. On April 20, 2005 , the family took advantage of the grief and appointed Nazek Hariri (Rafiq Hariri's widow) to be the prime minister.

Many studies on political dynasties have been massively carried out by scientists. Pablo Querubin [16] states that a political dynasty is a small group of families who make effort to distribute their political control to certain geographic areas. Then, Mark R. Thompson [17] states that a political dynasty is a transition from the old leadership position to the new leadership position that is carried out indirectly or directly by involving members of their families. Moreover, Yasushi Asako et al (2012: 5) [18] state that a political dynasty is a group of politicians who carry out the inheritance of their state office for members of their families. The main point of political dynasties is on the term family. In conclusion, political dynasties are efforts to preserve political control by placing family members in strategic positions or certain positions in the government.

Bathoro [19] explains that in modern politics political dynasties are considered as political elites based on marriage and blood ties so that some political observers refer it as a political oligarchy system. As shown by many studies and also discussions by experts from several countries, the establishement of political dynasties have a strong correlation with political interests of some families. The interests of the family have always been the main basis with regard to the expansion, growth and development of political dynasties towards a democratic political system. Family members in the kinship political tradition holding state officials will carry out practices such as nepotism by providing some special treatment to their relatives or family members (Agus, 2017: 7) [20].

Eisenstadt S.N. and Roniger Luis in Sutisna [21] state that giving strategic positions to family members is based on four reasons that are (1) trusty, that relatives do not betray and can be trusted ; (2) loyality, that relatives have high loyalty to carry out their political responsibilities; (3) solidarity, that relatives have solidarity with respect to bankruptcy from a position held by a family member or another relative; (4) protection, that relatives can maintain the honor of the family because they come from the same clan or identity which will have a preference to keep what the family has compared to other people.

\section{METHOD}

This study was conducted with a qualitative approach. The data was obtained from interviews, scientific journals, books, the internet, and research results. The data obtained were then analyzed using a phenomenological strategy by combining the results of the interviews and relevant theories. The result of this study is an explanation of the policy of Indonesian People's Wave Party (Gelora) in dealing the phenomenon of political dynasties. The result of this study broadens people's knowledge, especially for civic teachers and students about the policy of the Gelora Party as a relatively new party in Indonesia.

\section{RESULTS AND DISCUSSION}

\subsection{The Indonesian People's Wave Party (Gelora)}

Reporting from Kompas.com [12], the Indonesian People's Wave Party was established on November 10, 2019. The Indonesian People's Wave Party in Indonesia is Partai Gelombang Rakyat Indonesia and is commonly abbreviated as Partai Gelora. This political party has a plan to participate in the 2020 local election. Initially, the Gelora Party was a community organization, Indonesia's New Direction Movement Organization, which then transformed to a political party. In Indonesian, it is Ormas Gerakan Arah Baru Indonesia and is commonly abbreviated as Ormas Garbi. The Gelora Party was initiated by several figures. They are Fahri Hamzah, Anis Matta, Deddy Mizwar, Hadi Mulyadi, and Triwisaksana.

1. Fahri Hamzah

Fahri became the main figure behind the establisment of the Gelora Party. Fahri was a member of the Prosperous Justice Party. However, Fahri disagreed with the Prosperous Justice Party and in 2016 he was fired by the political party. He then demanded that the Prosperous Justice Party had to pay IDR 30 billion for compensation. Reporting from antaranews.com, Fahri said that the Gelora Party was formed because of a request by the members of the Ormas Garbi. Then, he and Anis Matta, the former president of the Prosperous Justice Party, established the Gelora Party together.

2. Anis Matta

Anis Matta is also another figure behind the establishment of the Gelora Party. It was Anis who initiated the establishment of the Ormas Garbi until the organization later became a political party. Reporting from kompas.com, the Ormas Garbi was established in South Sulawesi which then expanded to all of the country. He was the former President of the Prosperous Justice Party. However, in 2015 he was later replaced by Sohibul Iman who served for the 2015-2020 period.

3. Deddy Mizwar

Deddy Mizwar is a figure who gave a signal that he would join the Gelora Party through his Twitter account. When confirmed by kompas.com, Deddy also stated his plan to join the Gelora Party because 
he and the Gelora Party had the same vision. Deddy himself was a member of the Democratic Party. He had intended to resign from the Democratic Party after the Gelora Party officially became a political party.

4. Hadi Mulyadi

Hadi Mulyadi was the Vice Governor of East Kalimantan for the 2018-2023 period. Hadi was a member of the Prosperous Justice Party. He was also a member of the Shura Council of the Prosperous Justice Party for several periods. Before being a Vice Governor, Hadi had been the Vice Chairman of Regional People's Representative Council of East Kalimantan for the 2009-2014 period. He was also a member of the Indonesian People's Representative Council for the 2014-2019 period.

5. Triwisaksana

Triwisaksana was also a member of the Prosperous Justice Party. He was a Vice Chairman of the Regional People's Representative Council of the Jakarta Capital Special Region for two periods, the 2009-2014 period and the 2014-2019 period. Even though he was the Vice Chairman of the Regional People's Representative Council of the Jakarta Capital Special Region for two terms, he was not nominated himself for the 2019 legislative election.

One of the founders of the Gelora Party, Fahri Hamzah, stated that the purpose of establishing the party was to refute all the misleading dichotomies created from the past, including the dichotomy between Islam and nationalism and to fight back the threats that can destroy the Indonesian national unity. He also stated that political parties were the backbone of Indonesian democracy which meant political parties were a means to manage the government and manage the country. Moreover, he stated that there were no other arguments and the most important things were about how to solve problems in society, how to eradicate corruption, and how to eradicate terrorism.

\subsection{Gelora's Policies}

An interview was conducted with Ahmad Nurkholish, M.Pd. He was the Chairman of the Regional Leadership Council of People's Wave Party of Lampung. The interview was about the view of the Gelora Party on the phenomenon of political dynasties and the policy of the Gelora Party in dealing with the phenomenon of political dynasties.

Ahmad Nurkholish explained about the view of the Gelora Party on the phenomenon of political dynasties. He said that the direct democracy system opened up the possibility for all citizens of all backgrounds to take part in national or local elections, eEspecially when decentralized government system was implemented, the opportunity to take part in local and national elections is increasingly open to anyone.

However, because of the freedom, there is an anomaly in the direct democracy system that is political dynasties. According to the Constitutional Court, a political dynastic is a model of political control conducted by a group of people with family or kinship ties. Data from the Ministry of Home Affairs states that in 2016 there were no less than 60 political dynasties spread throughout Indonesia. The most popular is of course the Ratu Atut's political dynasty in Banten. This phenomenon of political dynasties does not appear by itself. There are factors that encourage this phenomenon to emerge and continue to grow.

The first factor is the process of regeneration within political parties. Political parties tend to be poweroriented. The second factor is the community's view of the candidate for regional head. The society prefers a candidate who has more political connections and is a relative of a famous political figure to a candidate who has competence. This is because the community wants to maintain the status quo of their regions by encouraging the regional heads to continuously have political control of the regions. This proves that feudalism is common in Indonesia. The third factor is bureaucratic culture. The incumbent has certainly built a bureaucratic culture for the government apparatus under him. Inevitably, the public officials must support the incumbent so that his career and income are not disturbed. This certainly strengthens the power of political dynasties because they have the support of the public officials. The Gelora Party views this as quite dangerous because it will lead to the culture of authoritarianism and increase the chances of corruption. Therefore, political dynasties must be immediately stopped and people are educated in order to be politically literate.

Moreover, Ahmad Nurkholish explained about the policy of the Gelora Party in dealing with the phenomenon of political dynasties. He said the policy of the Gelora party was to produce new political elites from the ordinary people by educating, trainning, and empowering them to be politically literate and aware and able to be independent in the economic field so that selfesteem could not be bought. The Gelora Party educates political elite candidates from an early age. This is grassroots politics, and it is believed that it can create a strong political network. Finally, when a local election is held, the members of the Gelora Party are able to change people's minds to choose the best candidate to lead them.

\section{CONCLUSION}

Based on the description above, the view of the Gelora Party on the factors that encourage this phenomenon to emerge and continue to grow that are (1) the process of regeneration within political parties which are still power-oriented, (2) society prefers a candidate who has more political connections and is a relative of a famous political figure to a candidate who has competence, (3) the incumbent has built a bureaucratic culture for the government apparatus under him. 
The Gelora Party has a new policy according to which they can minimize or even eliminate the phenomenon of political dynasties. This policy is to produce new political elites from the ordinary people by educating, trainning, and empowering them to be politically literate and aware and able to be independent in the economic field so that self-esteem could not be bought. The Gelora Party educates political elite candidates from an early age. This is grassroots politics, and it is believed that it can create a strong political network. Finally, when a local election is held, the members of the Gelora Party are able to change people's minds to choose the best candidate to lead them.

\section{AUTHORS' CONTRIBUTION}

This paper presents the "people's wave party policy regarding the phenomenon of political dynasties". This article discusses in detail the policies carried out by the Gelora party through direct interviews with the chairman of the DPD Bandar Lampung.

\section{REFERENCES}

[1] B. Prayoga. 2019. Studi Kebijakan Publik. Yogyakarta: Graha Ilmu.

[2] A. Idrus. 2019. Kembali Ke UUD 1945 Asli. Bandung: Kencana Utama.

[3] B. Prayoga. 2019. Studi Kebijakan Publik. Yogyakarta: Graha Ilmu.

[4] D. Thomas. 1981. Memahami Kebijakan Publik. Yogyakarta: Gajah Mada University Press.

[5] S. Sri. 2008. Modul 1: Konsep Dasar Kebijakan Publik. Semarang: Badan Penerbit Universitas Diponegoro.

[6] P. Bestari. 2019. Studi Kebijakan Publik. Yogyakarta: Graha Ilmu.

[7] B. Miriam. 2012. Dasar-dasar Ilmu Politik. Gramedia: Jakarta.

[8] R.S.K. William Crotty. 2014. Handbook Partai Politik. Bandung: Nusamedia.

[9] Efriza. 2012. Political Explore. Bandung: Alfabeta.

[10] M. Budiardjo. 2012. Dasar-dasar Ilmu Politik. Gramedia: Jakarta.

[11] P. Sigit. 2011. Partai Politik Teori dan Praktek di Indonesia. Yogyakarta: Institute democracy and Welfarism.

[12] Kompas. "Ormas Garbi, Fahri Hamzah, dan Perjalanan Partai Gelora”. https://www.kompas.com/tren/read/2019/11/08/09 1223465/ormas-garbi-fahri-hamzah-danperjalanan-partai-gelora. Diakses 29 Maret 2020.
[13] Synder. 2009. Political Dynasties. Los Angeles: The Review of Economic Studies.

[14] Amungsend, Inge. 2013. Dinasty or Democracy? Party Politics in Bangladesh. CMI Brief Journal. Vol 12 No 6.

[15] W. Vloeberghs. 2012. The Hariri Political Dynasty after the Arab Spring. Mediterranean Politics. Taylor \& Francis (Routledge). Vol 17 No 2

[16] Q. Pablo. 2010. Family and politics: Dynastic persistence in the Philippines. Unpublished: Manuscript, MIT.

[17] M. R. Thompson. 2012. Asia's Hybrid Dynasties. Asian Affairs, 43(2), 204-220.

[18] Asako, Y., Iida, T., Matsubayashi, T., \& Ueda, M. 2015. Dynastic politicians: Theory and evidence from Japan. Japanese Journal of Political Science. Vol 16 No 1.

[19] Bathoro. 2011. Perangkap Dinasti Politik Dalam Konsolidasi Demokrasi. Jurnal Fisip Umrah. Vol 2 No 2 hlm. 115-125

[20] S. Agus. 2017. Gejala Proliferasi Dinasti Politik Di Banten Era Kepemimpinan Gubernur Ratu Atut Chosiyah. Jurnal Politik Indonesia. Vol 2 No 2

[21] A. Sutisna. 2017. Gejala Proliferasi Dinasti Politik Di Banten Era Kepemimpinan Gubernur Ratu Atut Chosiyah. Jurnal Politik Indonesia. Vol 2 No 2 